1 Title: Defence gene expression profiling to Ascochyta rabiei aggressiveness in chickpea.

2

3 Authors: Audrey E. Leo ${ }^{1}$, Celeste C. Linde ${ }^{2}$, and Rebecca Ford ${ }^{3 *}$

4 Melbourne School of Land and Environment, The University of Melbourne, Victoria 3010,

5 Australia ${ }^{1}$, Evolution, Ecology and Genetics, Research School of Biology, 116 Daley Rd, The

6 Australian National University, Canberra, ACT 2601, Australia ${ }^{2}$, School of Natural Sciences,

7 Griffith University, Nathan Campus, Brisbane, Qld 4111, Australia ${ }^{3}$

8 Rebecca Ford (*Corresponding author)

$9 \quad$ Email: rebecca.ford@griffith.edu.au

10 Telephone: +61 (0) 737355066 


\section{$11 \quad$ Key message}

12 Significant differences in defence pathway-related gene expression were observed among 13 chickpea cultivars following A. rabiei infection. Differential gene expression is indicative of 14 diverse resistances, a theoretical tool for selective breeding.

16 Abstract

17 A high number of Ascochyta rabiei pathotypes infecting chickpea in Australia, has severely hampered efforts towards breeding for sustained quantitative resistance in chickpea. Breeding for sustained resistance will be aided by detailed knowledge of defence responses to isolates with different aggressiveness. As an initial step, the conserved and differential expressions of a suit of previously characterised genes known to be involved in fungal defence mechanisms were assessed among resistant and susceptible host genotypes following inoculation with high or low aggressive A. rabiei isolates. Using quantitative Real-Time PCR (qRT-PCR), fifteen defence-related genes, normalised with two reference genes, were temporally differentially expressed $(P<0.005)$ as early as 2 hours post inoculation of Genesis090 (resistant) or Kaniva (susceptible). The highly aggressive isolate, 09KAL09, induced vastly different expression profiles of eight key defence-related genes among resistant and susceptible genotypes. Six of these same genes were differentially expressed among ten host genotypes, inclusive of the best resistance sources within the Australian chickpea breeding program, indicating potential use for discrimination and selection of resistance "type" in future breeding pursuits. 

mechanisms

\section{Introduction}

Chickpea (Cicer arietinum L.) is an important food legume and break crop when grown in rotation with cereals and oilseeds, which ultimately improves yields and maintains soil fertility through atmospheric nitrogen fixation (Singh 1997; Dalal et al. 1998). Globally, 10.5 million tonnes of chickpea is produced annually (FAOSTAT 2013). However, the fungal pathogen Ascochyta rabiei (Pass.) Labr. constrains both production and quality (Nene et al. 1987; Gaur and Singh 1996). As a seed-borne pathogen, dissemination usually occurs through anthropogenic movement of seed as well as dispersal by wind and rain splash, which eventually affects all aerial plant parts (Pande et al. 2005).

A. rabiei spores germinate 12 hours post inoculation (hpi) (Pandey et al. 1987). Appresoria are formed at $24 \mathrm{hpi}$ and mucilaginous exudates are secreted to provide a tight contact with the host surface (Köhler et al. 1995). At this point, necrotrophic fungi are known to produce compounds, such as saponin detoxifying enzymes (Markham and Hille 2001), to suppress plant defence responses and prevent the signalling of host defence pathways (Staples and Mayer 2003). Once A. rabiei mycelia penetrate the host epidermal cells (Pandey et al. 1987), they expand and secrete cell wall degrading enzymes and toxins such as solanapyrone A, B and C (Hohl et al. 1990; Alam et al. 1989; Kaur 1995). Subsequently, pycnidia are formed in the host tissue 6 to 8 days later to complete the life cycle (Hohl et al. 1990).

54 Chickpea has both active and passive defence responses to stop initial pathogenic attacks and 55 to prevent successful invasion and spread to neighbouring cells (Coram and Pang 2006). 
56 Passive defence mechanisms include preformed structural and chemical barriers such as 57 glandular trichomes, which secrete antifungal isoflavones (Armstrong-Cho and Gossen 2005). Active defence systems in plants may employ $R$ genes to recognise pathogen-specific effectors encoded by the Avr genes (McDonald and Linde 2002), leading to effector-triggered immunity (ETI) and possible programmed cell death (PCD) via a hypersensitive response (HR) (Jones and Dangl 2006).

Few sources of stable resistance to A. rabiei exist. Singh and Reddy (1993) identified five (ICC4475, ICC6328, ICC12004, ILC200 and ILC6428) from 19,343 chickpea accessions resistant to six races of A. rabiei in Syria. The accession ICC3996 was added to this list by Chen et al. (2004) and together these have become the genetic basis of A. rabiei resistance breeding programs worldwide. However, some moderate resistance has recently broken down (Tar'an et al. 2007; Kanouni et al. 2002) and in 2010, the widely adopted resistant cultivars 'Genesis090' and 'PBA HatTrick' were heavily infected indicating that, as well as optimal environmental conditions, the pathogen may have increased aggressiveness.

Although, molecular studies of the 2010 Australian A. rabiei population uncovered a relatively low genetic diversity when measured with microsatellites and compared to that observed in other countries (Phan et al. 2003; Pradhan et al. 2006; Leo et al. 2011), the low diversity for neutral genetic markers may not accurately reflect the evolutionary adaptive potential for pathogenicity of the population. Indeed, when twenty four isolates with an identical microsatellite genotype were tested for their ability to cause disease on 12 Australian chickpea genotypes, extensive pathogenic variation (aggressiveness) was observed among the Australian cultivars and caused significant damage to the most current resistant cultivars (Elliott et al. 2011). This suggests that there may be differences in the perception, signalling and defence-related pathways among resistance sources to different isolates. 
The defence of chickpea to A. rabiei is multigenic and quantitative with resistancequantitative trait loci (R-QTL) identified on linkage groups 1, 2, 3, 4, 6 and 8 (Huettel et al. 2002; Flandez-Galvez et al. 2003; Iruela et al. 2006; Tar'an et al. 2007). This indicates that several defence-related mechanisms are involved as previously postulated (Tar'an et al. 2007). However, little is known on whether chickpea selectively employs differing types and levels of defence responses when infected with isolates of different aggressiveness known to exist in the Australian population (Elliott et al. 2011). One method to investigate this is to assess and compare, among host genotypes, the responsiveness of previously characterised defence-related genes that are representative of diverse defence-related pathways and following exposure to individual isolates of differing aggressiveness.

The expression profiles of several host genes, related to a range of defence mechanisms, have previously been characterised within the chickpea (ICC3996) - A. rabiei pathosystem (Coram and Pang 2005a; Coram and Pang 2005b; Coram and Pang 2006). For example, Pathogenesis Related (PR) proteins which are induced by pathogen-derived elicitors, such as glucan and chitin within fungal cell walls, as well as fungus-secreted glycoproteins and peptides (Kombrink and Schmelzer 2001; Edereva 2005). In particular, PR-2B ( $\beta 1,3$-glucanase) (EC 3.2.1.39) releases glycosidic fragments that elicit host defence mechanisms, and weakens and decomposes fungal cell walls containing glucans (Kombrink and Schmelzer 2001; Edereva 2005). The speed and coordination of pathogen perception by the host is vital to achieve effective defence. Resistant hosts often respond faster and produce larger quantities of defence related compounds than susceptible ones (Yang et al. 1997). For example, PR proteins $\beta$-1,3-glucanase and chitinase (EC 3.2.1.14) are more rapidly synthesized in resistant cultivars (Volgesang and Barz 1993; Hanselle and Barz 2001; Coram and Pang 2006; Vaghefi et al. 2013). 

protect uninfected cells from oxygen toxicity, suppress apoptosis (Coelho et al. 2010) and detoxify various compounds (Marrs 1996; Edwards et al. 2000; Dixon et al. 2002). The down-regulation of GST indicates an increase in cellular $\mathrm{H}_{2} \mathrm{O}_{2}$ from a possible oxidative burst (Neil et al. 2002). Another, Snakin-2 (SN2), is a broad-spectrum antimicrobial cysteine-rich peptide from potato (Solanum tubersum L.) (Segura et al. 1999), which is also known as gibberellins stimulated-like proteins (GSL2) (Meiyalaghan et al. 2014). The cysteine-rich nature of this peptide acts as both constitutive and inducible defence barriers crucial to the occurrence of disulphide bridges important in enhancing the structural stability of the plants when under stressful conditions (Berrocal-lobo et al. 2002; Pelegrini et al. 2011).

Other gene targets to asses defence to necrotrophic fungal pathogens have included the disease resistance response gene (DRRG) in pea (Pisum sativum) infected with Fusarium solani (Chiang and Hadwiger 1990) and those regulating the cellular oxidative burst in barley (Hordeum vulgare L,) infected with Botrytis cinerea. Also, members of the NAC (for NAM,

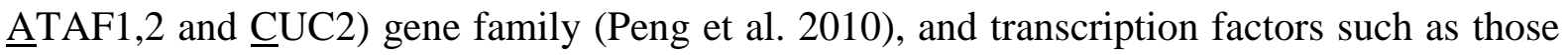
detected in Medicago truncatula following infection with Uromyces striatus (Madrid et al. 2010). One of these, TF1082, confers an ethylene response (ER) during infection (Madrid et al. 2010). Previously, the ERG (ethylene receptor gene) also known as CaETRI (Cicer arietinum L. Ethylene receptor-like sequences) was found to be responsive to A. rabiei infection (Madrid et al 2010). Another, TF1063, a myelobastosis (MyB) gene family member, was associated with the hypersensitive response (Madrid et al. 2010). Assessing the differential expression of these gene homologues in chickpea would aid in better understanding the complexities of defence-mechanism responses to A. rabiei. sensitively detect expression level changes of potentially low-abundance and previously 
characterised transcripts (Kakar et al. 2008). This approach was employed to compare the temporal and quantitative expression of key defence-related genes in chickpea to isolates that represent the breadth of aggressiveness within the Australian A. rabiei population. This will determine: 1) if isolates with different aggressiveness provoke differential host defence gene expressions, and the speeds in which these occur and 2) if different genes are expressed during the response, providing further evidence of different defence mechanisms among different chickpea genotypes.

\section{Material and methods}

\section{Plant material and fungal isolates}

Ten chickpea genotypes used in this experiment (Table 1) were chosen as a representative of a differential host range based on their previously determined disease reactions to 24 Australian A. rabiei isolates (Elliott et al. 2011). These included susceptible and resistant cultivars which are commercially used, as well as parental lines used in the Australian breeding program. All genotypes were obtained from the Victorian Department of Environment and Primary Industries in Horsham, Victoria, Australia. Chickpea genotypes, 'Genesis090' and 'Kaniva' which were categorised as resistant (Pulse Australia 2009c) and susceptible (Carter 1999), respectively, were used to screen and selectively identify differentially expressed defence-related genes prior to testing the genes on other chickpea genotypes.

A. rabiei isolates; 09KAL09, 09MEL04, 09KAN19 and 09KIN11 used in this study were collected in 2009 (Leo et al. 2015). The isolates comprised two sets of two isolates with different aggressiveness based on the mean area under disease progress curve (AUDPC) in 
the pathotyping study by Elliott et al. (2011) which used the disease rating scale adopted from Singh et al. (1981). Briefly, The number of times each treatment (isolate on host) received a particular score was determined based on the established 1-9 scale. Scores of $1 \& 3,5$ and 7 \& 9 were grouped into three categories. For leaf infection, isolates which at 21 days post inoculation had a score of 7 or 9 greater than $80 \%$ of the time were classified as high risk. Isolates with a score of 7 or 9 less than $60 \%$ of the time were classified as low risk. For stem infection, isolates which at 21 days post inoculation had a score of 7 or 9 greater than $10 \%$ of the time were classified as high risk. Isolates with a score of 7 or 9 less than $5 \%$ of the time were classified as low risk. Overall severity/rank was based on the highest risk rating from either the stem or leaf data if they did not match. The highly aggressive isolates, 09KAL09 and 09KAN19 were isolated from the resistant cultivar, Genesis090 in Kalkee and Kaniva, Victoria, respectively. The low aggressive isolates, 09MEL04 and 09KIN11 were isolated from the moderately resistant cultivars, CICA0503 and Almaz in Melton and Kingsford, South Australia, respectively.

\section{Bioassay}

All isolates were passaged on sterilised chickpea leaves (autoclaved at $80{ }^{\circ} \mathrm{C}$ for $15 \mathrm{mins}$ ) on $1 \%(\mathrm{w} / \mathrm{v})$ water agar for 1 week before being transferred onto V8 juice growth agar. Cultures were grown at $20 \pm 2{ }^{\circ} \mathrm{C}$ with a $12 \mathrm{~h}$ photoperiod for 14 days. Spore suspensions were then prepared by adding $10 \mathrm{~mL}$ of sterile water and scraping the spores off the plate with a scalpel. The spore suspensions were then filtered through a muslin cloth and the concentration adjusted to $1 \times 10^{5}$ spores $/ \mathrm{mL}$ using a haemocytometer.

Seeds were surface sterilized in $5 \%$ (w/v) sodium hypochlorite for 15 minutes and washed three times with sterile distilled water prior to sowing in $15 \mathrm{~cm}$ diameter pots (containing 3 
seeds each) in sterile soil. A total of four biological replicates per chickpea line per isolate

177 including mock controls was used. All plants were grown at $20 \pm 4{ }^{\circ} \mathrm{C}$ for 14 days (until six to eight leaf stage) before inoculation. Plants were then sprayed with A. rabiei spore suspensions until run-off (approximately $5 \mathrm{~mL} /$ plant). Mock-inoculated controls were sprayed with sterile distilled water until run off. Following inoculation, each pot was covered with a disposable plastic cup for maximum darkness and sealed in a plastic storage box in a $20 \pm 4{ }^{\circ} \mathrm{C}$ growth room to maintain humidity.

\section{RNA extraction, cDNA preparation and development of qRT-PCR-based markers}

185

Main stem and young leaf tissue weighed $100 \mathrm{mg}$ were collected from mock and spore inoculated plants at 2, 6, 12, 24, 48 and 72 hours post inoculation (hpi) for total RNA extraction using the RNeasy® Plant Mini Kit (Qiagen, CA, USA). RNase-Free DNase (Qiagen, CA, USA) was added to eliminate gDNA contamination. RNA concentration and integrity (RQI) values were determined on an Experion with RNA StdSens Chips (Bio-Rad Laboratories, CA, USA). RQI values higher than eight were used for downstream applications (Fleige and Pfaffl 2006). Total RNA (1 $\mu \mathrm{g})$ was reverse-transcribed with a combination of Oligo(dT) $)_{20}$ and random primer using the iScript ${ }^{\mathrm{TM}}$ select cDNA synthesis kit (Bio-Rad Laboratories, NSW, Australia). The quality of cDNA and absence of gDNA were assessed on agarose gel.

Seventeen genes including transcription factors which were highly and differentially expressed in various legume defence mechanisms (to mostly biotic but in some cases abiotic stress factors) were selected from the literature (Table 2). Sequences were derived from GenBank and three sets of qRT-PCR primers were designed from each using Primer3 v.0.4.0. (Rozen and Skaletsky 2000). The primers were designed with the following criteria: $\mathrm{T}_{m}$ of 60 
$200 \pm 1{ }^{\circ} \mathrm{C}$ and PCR amplicon size of 55-250 bp, primer sequences length of 18-27 nucleotides 201 and GC contents of 45-65\%. To normalise the relative quantities (NRQs) of these genes, 202 three reference genes (PUBQ, RIB, PP2A) (Table 2) previously proven to give stable 203 expressions after biotic stresses to Fusarium oxysporum f. sp. ciceris and A. rabiei in 204 chickpea were assessed (Castro et al. 2012). All primers were synthesised at Sigma-Genosys Ltd (NSW, Australia). All primers were tested with both randomly pooled cDNA and gDNA samples, and cycle sequenced three times at the Australian Genome Research Facility (AGRF, Melbourne, Australia) to determine the correct expected amplicon size and BLASTn to ensure the amplicons were of the target sequences.

All PCR were carried out with the iQ5 Real-Time PCR detection System (Bio-Rad Laboratories, NSW, Australia). A standard curve was produced for each of the target and reference genes. The $25 \mu \mathrm{L}$ reaction comprised $4 \mu \mathrm{L}$ of DNA template, $13.5 \mu \mathrm{L}$ of $1 \mathrm{X}$ iQSYBR Green Supermix (Bio-Rad Laboratories, NSW, Australia) and the specified primer concentration (Table 2). Thermal cycling conditions were: Initial denaturation at $95{ }^{\circ} \mathrm{C}$ for 1 $\min ; 40$ cycles of $95{ }^{\circ} \mathrm{C}$ for $10 \mathrm{~s}, 60{ }^{\circ} \mathrm{C}$ for $15 \mathrm{~s}, 72{ }^{\circ} \mathrm{C}$ for $30 \mathrm{~s}, 83{ }^{\circ} \mathrm{C}$ for $10 \mathrm{~s}$ (fluorescence reading), followed by melt curve analysis at $60-95^{\circ} \mathrm{C}$ every $0.5^{\circ} \mathrm{C}$ for $10 \mathrm{~s}$. All reactions were performed in triplicate and the sample maximisation layout strategy was employed (Hellemans et al. 2007). The cDNA samples for each gene were preferably run within a single plate to reduce technical, run-to-run variation. However, inter-run calibrators (IRC) were used whenever all samples could not be analysed in the same run. Minus reverse transcription control (-RTC) and no template control (NTC) were carried out for every gene to detect the presence of contaminating DNA and/or primer dimers. 

efficiency range of 95 to $110 \%$ were discarded.

227 Reference genes were analysed and selected based on stable expression using geNorm ${ }^{\text {PLUS }}$ (Hellemans et al. 2007). Normalization of expression values from targeted genes were calculated using qbase PLUS software, and were reported as normalized relative quantities (NRQs) (Hellemans et al. 2007).

General linear model was performed using SAS and Minitab 16 to determine differentially expressed genes at $P<0.05$. A mean fold change of 2.0 was used as the cut-off point. differentially expressed genes between genotypes, treatments, or genotype $\mathrm{x}$ treatment interactions, were clustered using an hierarchical cluster analysis. A data matrix for each genotype with the expression ratio was used to calculate an Euclidean distance matrix. The UPMG method was used to generate a dendogram using $K$-means clustering with Cluster v3.0 (Eisen et al. 1998) and viewed with Treeview v1.60 (Page 1996) as a heat map.

To assess for differences in host gene expression levels when infected with different isolates, the mean expressions derived from each interaction were compared and an analysis of variance (ANOVA) was then performed with qbase PLUS software $(P=0.05)$. The same analyses determined significant gene expression differences among ten chickpea genotypes (Table 1) infected with the aggressive isolate, 09KAL09. A total of eight defence genes which were up-regulated in 'Genesis090' when infected with 09KAL09 (CARNAC, GST, PR2B, SN2, ERG, PAMP, RGA4, TF1082) were selected to identify and determine potential responses induced among four other resistant, two moderately resistant and two moderately susceptible chickpea genotypes relative to the susceptible genotypes (Table 1) and compared using ANOVA. 
Single fragments of 80 to 250 bp were amplified with efficiencies of 90 to $110 \%$ from 15 of

251

252

253

254

255

256

257

258

259

260

261

262

263

264

265

266

267

268

269

270 the 17 target genes and were used to assess expression levels with qRT-PCR (Table 2). Of the sequences tested for suitability for expression normalisation, PUBQ and RIB were the most stable with $M$ (gene stability) values of 1.102 and coefficients of variation $(\mathrm{CV})$ values of 0.414 and 0.412 , respectively (Hellemans et al. 2007). The $M$ value for PP2A was 1.411 and thus excluded.

\section{Timing and expression levels of defence-related host genes based on interactions with} different levels of isolate aggressiveness

All 15 defence-related genes were differentially expressed in at least one time point following inoculation of 'Genesis090' and 'Kaniva' when compared to the un-inoculated controls. Of the four isolates assessed, the highly aggressive 09KAL09, produced a grossly different expression profile across all 15 genes. The most down-regulation, was consistent in timing and levels across both the resistant (Genesis090) and susceptible (Kaniva) genotypes (Figure 1). Conversely, the expression profile produced by the other highly aggressive isolate (09KAN19) was not largely different in either timing or magnitude to the two less aggressive isolates (09MEL04 and 09KIN11). Again, this was consistent among host genotypes (Figure 1, Figure 2). In general, the majority of differentially expressed genes were up-regulated as early as 2 hpi and started to be down-regulated at 72 hpi (Supplementary Material 1).

\section{Similarities in host gene expression trends among isolate interactions}


271 Cluster analysis shown similarities in individual gene expression profiles following exposure 272 to each of the four isolates (Figure 2). Mega Cluster I contained PR2B, up-regulated as early as 12 hpi in 'Kaniva' and 'Genesis090' regardless of isolate applied. Cluster II was divided into six subgroups. Cluster II.1:2 comprised ERG and LZP genes, which were not upregulated when either host genotype was inoculated with either 09KAL09 or 09MEL04, but were up-regulated when inoculated with 09KAN19 or 09KIN11 (as early as 2 hpi). Cluster II.2:3 comprised CARNAC, GST and SDCCP. CARNAC was up-regulated in all interactions except when Kaniva was inoculated with 09KAL09, suggesting that lack of expression may lead to susceptibility when inoculated with the highly aggressive isolates. GST and SDCCP contained TF1082, Cluster II.5:2 and Cluster II.6:1 comprised RGA10\&5, and SN2,

Following inoculation with isolate 09KAL09, major differences in the gene differential expression profiles were observed among the ten host genotypes assessed, which ranged in classification from resistant to susceptible (Supplementary material 2; Figure 3). The mean expression profiles of each genotype at a $95 \%$ confidence interval identified six genes, CARNAC, ERG, GST, RGA4, SN2 and TF1082, differentially expressed across all ten host 
genotypes (Supplementary material 2). The expression of PR2B was not differential but consistently highly up-regulated among all hosts. PAMP was up-regulated in all hosts except for the highly susceptible Kaniva, perhaps indicating a lack of recognition. To further identify which genes were up-regulated in the resistant and moderately resistant genotypes in comparison to the susceptible genotypes, the mean expression profiles of each genotype were categorised into their susceptibility levels and compared (Supplementary material 3 and Supplementary material 4). Between moderately resistant and resistant genotypes, only SN2 was differentially expressed, more highly in moderately resistant genotypes. Interestingly, no genes were differentially expressed between moderately resistant and moderately susceptible classified genotypes at any of the time points assessed, however, four genes, SN2, GST, ERG and RGA4, were differentially expressed between resistant/moderately resistant and susceptible genotypes. Three, SN2, GST, and ERG, were expressed at higher levels in resistant/moderately resistant than susceptible genotypes and one, RGA4, at a higher level in tools for future molecular selection of resistance within breeding programs.

\section{Discussion}

For the first time, they study has demonstrated that A. rabiei isolates of a similar high aggressiveness level are able to cause different host responses within the same chickpea genotype. One might postulate that 09KAL09 is able to evade detection and recognition and then goes on to suppress host defence responses whilst it establishes itself and begins to evade and colonise the tissues. Meanwhile 09KAN19, also highly aggressive, is detected and recognised almost immediately (and certainly by $2 \mathrm{hpi}$ ), causing the up-regulation of the 
spectrum of defence responses related to the genes under study. The question remains regarding what differentiates the ability for the 09KAL09 isolate to be highly aggressive compared to the two less aggressive isolates. Perhaps other isolate-related fitness characteristics are important in establishing and maintaining infection ahead of host defences? Certainly, the timing of gene expressions was largely indifferent following exposure to the highly aggressive 09KAN19 or either of the less aggressive isolates, indicating that molecular evidence of pathogenicity differences among these three isolates was not captured in this study and on these cultivars, hence a wider range of defence-related genes and cultivars would need to be assessed. This would be more feasible with whole genome transcriptomics in response to A. rabiei inoculation.

Another plausible reason to the down regulation of most differentially expressed genes in both susceptible and resistant genotypes is the production, deletion or selection of fungal effectors in 09KAL09 that impact on pathogen recognition. This may trigger different host defence mechanisms. Positive selection occurring within the effector proteins has been observed quite extensively for Phytophtora sojae of soybean (Jiang et al. 2008). This was postulated as a mechanism employed to enable escape from host resistance protein detection programmed cell death (PCD) and also abolished the avirulence interaction of Avr1b with the Rps $1 b$ resistance gene in soybean (Dou et al. 2008). A similar mechanism may be occurring within A. rabiei isolate 09KAL09, enabling it to evade detection by chickpea.

During industry establishment, selection of a narrow gene pool and subsequent inbreeding has led to a lack of genome diversity across cultivated chickpea, which has also likely constricted the potential diversity of defence mechanisms retained within Australian chickpea cultivars. This low diversity of defence mechanisms was shown in the considerably fewer 
number of disease resistance gene homologues in chickpea in comparison to other legume species (Varshney et al. 2013). However, significant differences in expression levels and timings of the 15 defence-related genes assessed in the current study were detected among the 10 host genotypes assessed. At very early time points (2-6 hpi) these are likely related to differences in the timing of pathogen recognition and subsequent speed to signal downstream defence mechanisms.

Indeed, the faster expression of GST in 'Kaniva' (6 hpi) compared to 'Genesis090' (24 hpi) is likely associated with the earlier accumulation of $\mathrm{H}_{2} \mathrm{O}_{2}$ in the susceptible cultivar to trigger a rapid hypersensitive response. However, across genotypes, the susceptible genotypes produced significantly less GST than the resistant ones at earlier time points and greater expression in the resistant genotypes later on (24 to $48 \mathrm{hpi}$ ). This may indicate that although the hypersensitive response is employed by susceptible genotypes this is not effectual for containing the pathogen and that resistant genotypes only instigate this defence response after other first-line defence responses have been triggered. Indeed, other reactive oxygen species involved in the precursors to the hypersensitive response have been detected in resistant genotypes at earlier time points of the interaction (Hohl et al. 1990; Coram and Pang 2006).

The pattern of expression of SN2 was similar to GST (another antioxidant) with greater quantities detected in resistant/moderately resistant genotypes than susceptible genotypes. This is in accordance to the up-regulation of SN2 previously detected in ICC3996 (Coram and Pang 2005b; Coram and Pang 2006). Sequence similarities of SN2 peptides to GIP2 (GASA-like protein) from Petunia hybrida suggests involvement in redox regulations which regulate the production of reactive oxygen species in pathogenesis and wounding (Berrocallobo et al 2002; Wigoda et al. 2006; Balaji and Smart 2012). 
Meanwhile, CaETR1 (Cicer arietinum L. Ethylene receptor-like sequences) was the first ethylene receptor discovered in chickpea associated with A. rabiei resistance (Madrid et al 2010). The ERG locus is closely linked to a major QTL, QTL $\mathrm{AR}_{\mathrm{A} 1}$ proposed to condition resistance to pathotype II (Iruela et al. 2006; Madrid et al. 2012). Recently, the CaETRI and CaETR-1a/CaETR-1b alleles from resistant and susceptible chickpea genotypes (Madrid et al. 2012) were used to negatively select and eliminate susceptible individuals from a breeding program (Madrid et al. 2013). The differential expression of the allele (unknown) observed in the current study between resistant/moderately resistant and susceptible genotypes may further indicate its suitability for resistance selection across broad range of germplasm.

A spectrum of differences in levels and timings of the CARNAC transcription factor was observed among the 10 genotypes. Down- or unaltered expression in the majority of genotypes may be related to involvement in developmental processes such as apical meristem development, flowering and secondary wall formation (Peng et al. 2010), This may be anticipated in response to a pathogen attack, as reserves are rerouted to defence-related activities (Coram and Pang 2006). However, up-regulation witnessed in Almaz, Genesis114, Genesis090 and Kaniva may have been directly related to defence responses through participation in signalling pathways and regulatory networks (Nuruzzaman et al. 2013). Indeed, NAC proteins activate PR genes, induce the hypersensitive response and cause cell death at the infection site (Kaneda et al. 2009; Seo et al. 2010). NAC proteins also have the ability to form alliances with certain host regulatory complexes, enabling them to act as negative regulators of the defence response by suppressing defence-related genes (Wang et al. 2009).

Meanwhile, PR proteins are pathogen-induced proteins classified into 17 families from PR-1 to PR-17, based on biochemical properties (Van Loon et al. 2006). As observed for PR2B in the current study, they may be expressed prior to infection due to involvement in plant 
development (Edereva 2005), accumulated and synthesized for a long lag period. They may then be translocated from the site of induction to other plant parts during pathogenic attack (Matsuoka and Ohashi 1986). Ultimately, PR2B ( $\beta 1,3$-glucanase) produces glycosidic fragments which weakens and decomposes fungal cell walls containing glucans, chitin and proteins (Kombrink and Schmelzer 2001; Edereva 2005). As previously reported, the PR2B gene was significantly up-regulated at 48 to 72 hpi compared to other time points, particularly in 'Genesis114', 'PBA HatTrick', 'Almaz', 'Genesis090' and 'Kaniva' (Hanselle and Barz 2001; Coram and Pang 2006; Cho and Muehlbauer 2004).

The gene deemed to regulate polymorphic antigen proteins (PAMP) was up-regulated at 12 and 48 hpi in all genotypes except for the susceptible 'Kaniva'. This gene is likely to be a homologue of Enolase phosphatise E1 protein, a bifunctional enzyme of methionine salvage that regenerates methionine from 5'-methylthioadenosine (MTA) (Wang et al. 2005). Its function in the resistance response is likely via its metabolism that utilises polyamines (PAs), nicotianamines (NAs) and interacts with ethylene biosysnthesis (Waduwara-Jayabahu et al. 2012). PAs are associated with cell division as a response to abiotic and biotic stress (Takahashi and Kakehi 2010; Vera-Sirera et al. 2010). NAs act as chelators for long distance ion transport and defence signalling processes (Curie et al. 2009), and ethylene is a phytohormone capable of signalling within defence pathways.

The transcription factor TF1082 was increasingly upregulated in several resistant and moderately resistant genotypes from 48 hpi onwards after exposure to the highly aggressive isolate 09KAL09. Previously, in Medicago truncatula infected with Uromyces striatus, this gene was up-regulated in resistant genotypes and down-regulated in susceptible genotypes, thought to bind to the GCC box of PR gene promoters and confer ethylene responsiveness (Madrid et al. 2010). 
416 In conclusion, this study showed that chickpea has a number of defence-related mechanisms

417 which are activated simultaneously to mount defence to A. rabiei, confirming that it is a race-

418 nonspecific resistance controlled by genes with minor to intermediate and additive effects.

419 Although a small subset of genes was assessed, several were differentially expressed among 420 cultivars, further indicating the potential of different defence mechanisms in chickpea under 421 controlled conditions where all plants are subjected to the same environment conditions. 422 Further studies such as RNA sequencing and identifying sequence polymorphisms of within 423 or upstream or downstream signalling regions of the differentially expressed genes in 424 susceptible and resistant cultivars may identify potential allelic differences that, once 425 functionally validated, could be converted into stable markers for future selective breeding purposes. Breeding chickpea genotypes containing several defence strategies will improve durability against the pathogenic diversity of the pathogen population.

\section{Author contributions}

AEL participated in the design of the experiment, carried out the experimental work, performed the statistical analyses, and drafted the manuscript. CCL assisted in revising the manuscript. RF participated in the design of the experiment and drafted the manuscript. All authors read and approved the final manuscript.

\section{Acknowledgements}


439 The authors declare that they have no conflict of interest.

440

\section{$441 \quad$ References}

442 Alam SS, Bilton JM, Slavin AMZ, Williams DJ, Sheppard RN, Strange RN (1989) Chickpea 443 blight: production of the phytotoxins solanapyrones $\mathrm{A}$ and $\mathrm{C}$ by Ascochyta rabiei. 444 Phytochemist 28:2627-2630

445 Armstrong-Cho C, Gossen BD (2005) Impact of glandular hair exudates on infection of 446 chickpea by Ascochyta rabiei. Can J Botany 83:22-27

447 Balaji V, Smart CD (2012) Over-expression of snakin-2 and extensin-like protein genes 448 restricts pathogen invasiveness and enhances tolerance to Clavibacter michiganensis subsp. 449 michiganensis in transgenic tomato (Solanum lycopersicum). Transgenic Res 21:23-37

450 Berrocal-Lobo M, Molina A, Solano R (2002) Constitutive expression of ETHYLENE451 RESPONSE-1 FACTOR1 in Arabidopsis confers resistance to several necrotrophic 452 fungi. The Plant J 29:23-32

453 Carter JM (1999) Chickpea growers guide: a guide for the production of chickpeas. 454 Agriculture Victoria, Department of Natural Resources and Environment

455 Castro P, Román B, Rubio J, Die JV (2012) Selection of reference genes for expression 456 studies in Cicer arietinum L.: analysis of cyp81E3 gene expression against Ascochyta rabiei. 457 Mol Breed 29: 261-274 
458 Chen W, Coyne CJ, Peever TL, Muehlbauer FJ (2004) Characterization of chickpea 459 differentials for pathogenicity assay of ascochyta blight and identification of chickpea 460 accessions resistant to Didymella rabiei. Plant Pathol 53:759-769

461 Chiang CC, Hadwiger LA (1990) Cloning and characterization of a disease resistance 462 response gene in pea inducible by Fusarium solani. Mol Plant Microbe Interact 3:78-85

463 Cho S, Muehlbauer FJ (2004) Genetic effect of differentially regulated fungal response genes 464 on resistance to necrotrophic fungal pathogens in chickpea (Cicer arietinum L.). Physiol Mol Plant Pathol 64:57-66

466 Coelho LP, Peng T, Robert FM (2010) Quantifying the distribution of probes between 467 subcellular locations using unsupervised pattern unmixing. Bioinformatics 26: i7-i12

468 Coram TE, Pang EC (2005a) Isolation and analysis of candidate ascochyta blight defence 469 genes in chickpea. Part I. Generation and analysis of an expressed sequence tag (EST) 470 library. Physiol Mol Plant Pathol 66:192-200

471 Coram TE, Pang EC (2005b) Isolation and analysis of candidate ascochyta blight defence 472 genes in chickpea. Part II. Microarray expression analysis of putative defence-related 473 ESTs. Physiol Mol Plant Pathol 66:201-210

474 Coram TE, Pang EC (2006) Expression profiling of chickpea genes differentially regulated 475 during a resistance response to Ascochyta rabiei. Plant Biotech J 4: 647-666

476 Curie C, Cassin G, Couch D, Divol F, Higuchi K, Le Jean M, Misson J, Schikora A, Czernic 477 P, Mari S (2009) Metal movement within the plant: contribution of nicotianamine and yellow 478 stripe 1-like transporters. Ann Bot 103:1-11 
479 Dalal RC, Strong VM, Weston EJ, Cooper JE, Wildermuth GB, Lehane KJ, King AJ, Holmes

480 CJ (1998) Sustaining productivity of a Vertisol at Warra, Queensland, with fertilisers, no-

481 tillage, or legumes. 5. Wheat yields, nitrogen benefits and water-use efficiency of chickpea-

482 wheat rotation. Animal Prod Sci 38:489-501

483 Dixon DP, Lapthorn A, Edwards R (2002) Plant glutathione transferases. Genome 484 Biol 3:3004-1Edereva A (2005) Pathogenesis-related proteins: research progress in the last 48515 years. Gen Appl Plant Physiol 31:105-124

486 Dou D, Kale SD, Wang X, Jiang RH, Bruce NA, Arredondo FD, Zhang X, Tyler BM (2008) 487 RXLR-mediated entry of Phytophthora sojae effector Avr1b into soybean cells does not 488 require pathogen-encoded machinery. The Plant Cell Online 20:1930-1947

489 Edwards R, Dixon DP, Walbot V (2000) Plant glutathione S-transferases: enzymes with 490 multiple functions in sickness and in health. Trends plant Sci 5:193-198

491 Eisen MB, Spellman PT, Brown PO, Botstein D (1998) Cluster analysis and display of 492 genome-wide expression patterns. Proc Natl Acad Sci 95:14863-14868

493 Elliott VL, Taylor PW, Ford R (2011) Pathogenic variation within the 2009 Australian 494 Ascochyta rabiei population and implications for future disease management 495 strategy. Australasian Plant Pathol 40:568-574

496 Ellis JG, Rafiqi M, Gan P, Chakrabarti A, Dodds PN (2009) Recent progress in discovery and 497 functional analysis of effector proteins of fungal and oomycete plant pathogens. Curr Op 498 Plant Biol 12:399-405

499 FAOSTAT (2013) Food and Agriculture Organization of the United Nations. 500 http://faostat.fao.org/. Accessed 13 February 2014 
501 Flandez-Galvez H, Ades PK, Ford R, Pang ECK, Taylor PWJ (2003) QTL analysis for 502 ascochyta blight resistance in an intraspecific population of chickpea (Cicer arietinum L.).

503 Theor Appl Genet 107:1257-1265

504 Fleige S, Pfaffl MW (2006) RNA integrity and the effect on the realtime qRT-PCR 505 performance. Mol Aspects Med 27:126-139

506 Gaur RB, Singh RD (1996) Effects of Ascochyta blight on grain yield and protein in 507 chickpea. Indian. J Mycol Plant Pathol 26:259-262

508 Hanselle T, Barz W (2001) Purification and characterisation of the extracellular PR-2b $\beta-1$, 509 3-glucanase accumulating in different Ascochyta rabiei infected chickpea (Cicer arietinum $510 \quad$ L.) cultivars. Plant Sci 161:773-781

511 Hellemans J, Mortier G, De Paepe A, Speleman F, Vandesompele J (2007) qBase relative 512 quantification framework and software for management and automated analysis of real-time 513 quantitative PCR data. Genome Biol 8:R19

514 Hohl B, Pfautsch M, Barz W (1990) Histology of disease development in resistant and 515 susceptible cultivars of chickpea (Cicer arietinum L.) inoculated with spores of Ascochyta 516 rabiei. J Phytopathol 129:31-45

517 Huettel B, Santra D, Muehlbauer FJ, Kahl G (2002) Resistance gene analogues of chickpea 518 (Cicer arietinum L.): isolation, genetic mapping and association with a Fusarium resistance 519 gene cluster. Theor Appl Genet 105:479-490

520 Iruela M, Rubio J, Barro F, Cubero JI, Millán T, Gil J (2006) Detection of two quantitative 521 trait loci for resistance to ascochyta blight in an intra-specific cross of chickpea (Cicer 522 arietinum L.): development of SCAR markers associated with resistance. Theor Appl Genet 112:278-287 
524 Jiang RH, Tripathy S, Govers F, Tyler BM (2008) RXLR effector reservoir in two 525 Phytophthora species is dominated by a single rapidly evolving superfamily with more than 526700 members. Proc Natl Acad Sci 105:4874-4879

527 Jones JD, Dangl JL (2006) The plant immune system. Nature 444:323-329

528 Kaneda T, Taga Y, Takai R, Iwano M, Matsui H, Takayama S, Isogai A, Che FS (2009) The 529 transcription factor OsNAC4 is a key positive regulator of plant hypersensitive cell 530 death. The EMBO J 28:926-936

531 Kanouni H, Arbat HK, Moghaddam M, Neyshabouri MR (2002) Selection of chickpea (Cicer 532 arietinum L) entries for drought resistance. Agri Sci (Tabriz) 12:109-121

533 Kakar K, Wandrey M, Czechowski T, Gaertner T, Scheible WR, Stitt M, Torres-Jerez I, Xiao 534 Y, Redman JC, Wu HC, Cheung F, Town CD, Udvardi MK (2008) A community resource 535 for highthroughput quantitative RT-PCR analysis of transcription factor gene expression 536 in Medicago truncatula. Plant Meth 4:18

537 Kaur S (1995) Phytotoxicity of solanapyrones produced by the fungus Ascochyta rabiei and 538 their possible role in blight of chickpea (Cicer arietinum). Plant Sci 109:21-29

539 Köhler G, Linkert C, Barz W (1995) Infection studies of Cicer arietinum (L.) with GUS-(E. 540 coli $\beta$-glucuronidase) transformed Ascochyta rabiei strains. J Phytopathol 143:589-595

541 Kombrink E, Schmelzer E (2001) The hypersensitive response and its role in local and 542 systemic disease resistance. Euro J Plant Pathol 107:69-78

543 Leo AE, Ford R, Linde CC, Shah RM, Oliver R, Taylor PWJ, Lichtenzveig J (2011) 544 Characterization of fifteen newly developed microsatellite loci for the chickpea fungal 545 pathogen Ascochyta rabiei. Mol Ecol Res 11:418-421 
546 Leo AE, Ford R, Linde CC (2015) Genetic homogeneity of a recently introduced pathogen of 547 chickpea, Ascochyta rabiei, to Australia. Biol Inv 17:609-623

548 Meiyalaghan S, Thomson SJ, Fiers MW, Barrell PJ, Latimer JM, Mohan S, Eirian Jones E, 549 Conner AJ, Jacobs JM (2014) Structure and expression of GSL1 and GSL2 genes encoding 550 gibberellin stimulated-like proteins in diploid and highly heterozygous tetraploid potato 551 reveals their highly conserved and essential status. BMC genomics 15:2

552 Madrid E, Gil J, Rubiales D, Krajinski F, Schlereth A, Millán T (2010) Transcription factor 553 profiling leading to the identification of putative transcription factors involved in the 554 Medicago truncatula-Uromyces striatus interaction.Theo Appl Gen 121:1311-1321

555 Markham JE, Hille J (2001) Host-selective toxins as agents of cell death in plant-fungus 556 interactions. Mol Plant Pathol 2:229-239

557 Marrs KA (1996) The functions and regulation of glutathione $S$-transferases in plants. Ann $558 \quad$ Rev Plant Biol 47:127-158

559

560

561

562

563

564

565

566

567

Madrid E, Rajesh PN, Rubio J, Gil J, Millán T, Chen W (2012) Characterization and genetic analysis of an EIN4-like sequence (CaETR-1) located in QTLAR1 implicated in ascochyta blight resistance in chickpea. Plant Cell Reports 31:1033-1042

Madrid E, Chen W, Rajesh PN, Castro P, Millán T, Gil J (2013) Allele-specific amplification for the detection of ascochyta blight resistance in chickpea. Euphytica 189:183-190

Matsuoka M, Ohashi Y (1986) Induction of pathogenesis-related proteins in tobacco leaves. Plant Physiol 80:505-510

McDonald BA, Linde C (2002) Pathogen population genetics, evolutionary potential, and durable resistance. Ann Rev Phytopathol 40: 349-379 
568 Nasir M, Bretag TW, Kaiser WJ, Meredith KS, Brouwer JB (2000) Screening chickpea 569 germplasm for ascochyta blight resistance. Australas Plant Pathol, 29:102-107

570 Neill SJ, Desikan R, Clarke A, Hurst RD, Hancock JT (2002) Hydrogen peroxide and nitric 571 oxide as signalling molecules in plants. J Exp Botany, 53:1237-1247

572 Nene YL, Reddy MV, Saxena MC, Singh KB (1987) Chickpea diseases and their 573 control. The Chickpea 233-270

574 Nuruzzaman M, Sharoni AM, Kikuchi S (2013) Roles of NAC transcription factors in the 575 regulation of biotic and abiotic stress responses in plants. Frontiers Microbiol 4:248

576 Page RDM (1996) TreeView: An application to display phylogenetic trees on personal 577 computers. Comput Appl Biosci 12:357-358

578 Pande S, Siddique KHM, Kishore GK, Bayaa B, Gaur PM, Gowda CLL., Gowda TW, Bretag 579 TW, Crouch, JH (2005) Ascochyta blight of chickpea (Cicer arietinum L.): a review of 580 biology, pathogenicity, and disease management. Crop Pasture Sci 56:317-332

581 Pandey BK, Singh US, Chaube HS (1987) Mode of infection of Ascochyta blight of chickpea caused by Ascochyta rabiei. J Phytopathol 119:88-93

583 Pelegrini PB, Perseghini del Sarto RP, Silva ON, Franco OL, Grossi-de-Sa MF (2011) 584 Antibacterial peptides from plants: What they are and how they probably work. Biochem Res 585 Int doi:10.1155/2011/250349

586 Peng H, Yu XW, Cheng HY, Shi QH, Zhang H, Li JG, Ma H (2010) Cloning and 587 characterization of a novel NAC family gene CarNACl from Chickpea (Cicer arietinum L.). 588 Mol Biotechnol 44:30-40 
589 Phan HTT, Ford R, Taylor PWJ (2003) Population structure of Ascochyta rabiei in Australia 590 based on STMS fingerprints. Fungal Div 13:111-129

591 Pradhan P (2006) Studies of Ascochyta rabiei in Australia. M Agr Sci thesis, University of 592 Melbourne

593 Pulse Australia (2009a) Almaz. Pulse variety management package.

594 http://www.pulseaus.com.au/storage/app/media/crops/2009_VMP-Kchickpea-Almaz.pdf.

595 Accessed 24 July 2015

596 Pulse Australia (2009b) Flipper. Pulse variety management package.

597 http://www.pulseaus.com.au/storage/app/media/crops/2009_VMP-Dchickpea-Flipper.pdf.

598 Accessed 24 July 2015

599 Pulse Australia (2009c) Genesis090. Pulse variety management package. 600 http://www.pulseaus.com.au/storage/app/media/crops/2011_VMP-Kchickpea-

601 Genesis090.pdf. Accessed 24 July 2015

602 Pulse Australia (2009d) Genesis114. Pulse variety management package.

603 http://www.pulseaus.com.au/storage/app/media/crops/2010_VMP-Kchickpea-

604 Genesis114.pdf. Accessed 24 July 2015

605 Pulse Australia (2009e) Genesis509. Pulse variety management package.

606 http://www.pulseaus.com.au/storage/app/media/crops/2009_VMP-Dchickpea-

607 Genesis509.pdf. Accessed 24 July 2015

608 Pulse Breeding Australia (2009) PBA HatTrick.

609 http://www.pulseaus.com.au/storage/app/media/crops/2011_VMP-Dchickpea-

$610 \quad$ PBAHatTrick.pdf. Accessed 24 July 2015 
611 Rozen S, Skaletsky H (2000) Primer3 on the WWW for general users and for biologist 612 programmers. Methods Mol Biol 132:365-386

613 Segura A, Moreno M, Madueno F, Molina A, Garcia-Olmedo F (1999) Snakin-1, a peptide 614 from potato that is active against plant pathogens. Mol Plant Microbe Interact 12:16-23

615 Seo PJ, Kim MJ, Park JY, Kim SY, Jeon J, Lee YH, Kim J, Park CM (2010) Cold activation 616 of a plasma membrane-tethered NAC transcription factor induces a pathogen resistance 617 response in Arabidopsis. The Plant J 61:661-671

618 Singh KB (1997) Chickpea (Cicer arietinum L.). Field Crops Res 53:161-170

619 Singh KB, Reddy MV (1993) Sources of resistance to ascochyta blight in wild Cicer 620 species. Netherlands J Plant Pathol 99:163-167

621 Singh KB, Hawtin GC, Nene YL, Reddy MV (1981) Resistance in chickpea to ascochyta 622 blight. Plant Dis 65: 586-587

623 Staples RC, Mayer AM (2003) Suppression of host resistance by fungal plant pathogens 624 REVIEW. Israel J Plant Sci 51:173-184

625 Takahashi T, Kakehi JI (2010) Polyamines: ubiquitous polycations with unique roles in 626 growth and stress responses. Ann Bot 105:1-6

627 Tar'an B, Warkentin T, Tullu A, Vandenberg A (2007) Genetic relationships among 628 Chickpea (Cicer arietinum L.) genotypes based on the SSRs at the quantitative trait loci for 629 resistance to Ascochyta blight. Eur J Plant Pathol 119:39-51

630 Vaghefi N, Mustafa BM, Dulal N, Selby-Pham J, Taylor PWJ, Ford R (2013) A novel 631 pathogenesis-related protein (LcPR4a) from lentil, and its involvement in defence against 632 Ascochyta lentis. Phytopathol Mediterranea 52:192-201 
633 Van Loon LC, Rep M, Pieterse CMJ (2006) Significance of inducible defense-related 634 proteins in infected plants. Annu Rev Phytopathol 44:135-162

635 Varshney RK, Song C, Saxena RK, Azam S, Yu S, Sharpe AG, Sharpe AG, Cannon S et al 636 (2013) Draft genome sequence of chickpea (Cicer arietinum) provides a resource for trait 637 improvement. Nature Biotech 31:240-246

638 Vera-Sirera F, Minguet EG, Singh SK, Ljung K, Tuominen H, Blázquez MA, Carbonell J 639 (2010) Role of polyamines in plant vascular development. Plant Physiol Biochem 48:534-539

640 Vogelsang R, Barz W (1993) Purification, characterization and differential hormonal 641 regulation of a $\beta$-1, 3-glucanase and two chitinases from chickpea (Cicer arietinum 642 L.). Planta 189:60-69

643 Waduwara-Jayabahu I, Oppermann Y, Wirtz M, Hull ZT, Schoor S, Plotnikov AN., Sauter 644 M, Moffatt BA (2012) Recycling of methylthioadenosine is essential for normal vascular 645 development and reproduction in Arabidopsis. Plant Physiol 158:1728-1744

646 Wang H, Pang H, Bartlam M, Rao Z. (2005) Crystal structure of human E1 enzyme and its 647 complex with a substrate analog reveals the mechanism of its phosphatase/enolase activity. J 648 Mol Biol 348:917-926

649 Wang XE, Basnayake BVS, Zhang H, Li G, Li W, Virk N, Mengiste T, Song F (2009) The 650 Arabidopsis ATAF1, a NAC transcription factor, is a negative regulator of defense responses 651 against necrotrophic fungal and bacterial pathogens. Mol Plant-Microbe Interact 22:1227652 1238Wigoda N, Ben-Nissan G, Granot D, Schwartz A, Weiss D (2006) The gibberellin653 induced, cysteine-rich protein GIP2 from Petunia hybrida exhibits in planta antioxidant activity. The Plant J 48:796-805 
655 Yang Y, Shah J, Klessig DF (1997) Signal perception and transduction in plant defense 656 responses. Genes Dev 11:1621-1639

657 Table 1. Chickpea genotypes and disease ratings to A. rabiei in Australia

\begin{tabular}{lll}
\hline Genotype & Disease rating & Citation \\
\hline Genesis090 & Resistant (R) & Pulse Australia (2009c) \\
PBA HatTrick & Resistant (R) & Pulse Breeding Australia (2009) \\
$90102-5$ Q-1103 & Resistant (R) & K. Hobson (pers. comm.) \\
$94-121 * 99 V 4006$ & Resistant (R) & K. Hobson (pers. comm.) \\
ICC3996 & Resistant (R) & Nasir et al. 2000 \\
Genesis114 & Moderately resistant (MR) & Pulse Australia (2009d) \\
Flipper & Moderately resistant (MR) & Pulse Australia (2009b) \\
Almaz & Moderately susceptible (MS) & Pulse Australia (2009a) \\
Howzat & Moderately susceptible (MS) & Pulse Australia (2009e) \\
Kaniva & Susceptible (S) & Carter (1999) \\
\hline
\end{tabular}


Table 2. Novel and published genes and primers used for differential gene expressions in

660 chickpea genotypes

\begin{tabular}{|c|c|c|c|c|c|c|}
\hline Gene ID & $\begin{array}{l}\text { Gene name } \\
\text { (abbreviatio } \\
\text { n) } \\
\end{array}$ & $\begin{array}{l}\text { Biological } \\
\text { significance }\end{array}$ & Primers & $\begin{array}{l}\text { Prime } \\
\text { r conc } \\
(\mu \mathrm{M})\end{array}$ & $\begin{array}{l}\text { Produ } \\
\text { ct size } \\
\text { (bp) } \\
\end{array}$ & $\begin{array}{l}\text { Referen } \\
\text { ce }\end{array}$ \\
\hline CV793598 & $\begin{array}{l}\text { Pathogenesis } \\
\text {-related } \\
\text { protein 2B } \\
(\text { PR2B })\end{array}$ & $\begin{array}{l}\beta-1,3- \\
\text { Glucanase - } \\
\text { hydrolysis of } \\
\text { flavonoid } \\
\text { and } \\
\text { isoflavonoid } \\
\text { compounds }\end{array}$ & $\begin{array}{l}\text { F: } \\
\text { GCCTAGAAAGGCAAATCCTT } \\
\text { C } \\
\text { R: } \\
\text { CATCTGCCGTGGGAATAAGA }\end{array}$ & 0.15 & 153 & $\begin{array}{l}\text { Coram } \\
\text { and Pang } \\
2006\end{array}$ \\
\hline DY475248 & $\begin{array}{l}\text { Polymorphic } \\
\text { antigen } \\
\text { membrane } \\
\text { protein } \\
\text { (PAMP) }\end{array}$ & $\begin{array}{l}\text { Transcriptio } \\
\mathrm{n} \text { of defence- } \\
\text { related genes } \\
\text { - resistance } \\
\text { response via } \\
\text { metabolism } \\
\text { utilising } \\
\text { polyamines } \\
\text { (PA) and } \\
\text { nicotianamin } \\
\text { es (NAs) }\end{array}$ & $\begin{array}{l}\text { F: } \\
\text { CCGCTGATACAGTGGAGGTT } \\
\text { R: } \\
\text { GTTTCCCCAATTTCCTCACC }\end{array}$ & 0.30 & 166 & \\
\hline DY475250 & $\begin{array}{l}\text { Glutathione } \\
S \text {-transferase } \\
(\mathrm{GST})\end{array}$ & $\begin{array}{l}\text { Regulation } \\
\text { of host } \\
\text { cellular } \\
\mathrm{H}_{2} \mathrm{O}_{2}\end{array}$ & $\begin{array}{l}\text { F: } \\
\text { TCCCTCCAACCTACTAACAA } \\
\text { GG } \\
\text { R: } \\
\text { TTTGGATTGGATAAGATTTG } \\
\text { GTTT }\end{array}$ & 0.30 & 119 & \\
\hline CV793608 & $\begin{array}{l}\text { SNAKIN2 } \\
\text { antimicrobia } \\
1 \text { peptide } \\
\text { precursor } \\
\text { (SN2) }\end{array}$ & $\begin{array}{l}\text { Regulate the } \\
\text { production } \\
\text { of reactive } \\
\text { oxygen } \\
\text { species } \\
\text { (ROS) in } \\
\text { host and } \\
\text { enhance host } \\
\text { structural } \\
\text { ability } \\
\text { through } \\
\text { disulphide } \\
\text { bridges }\end{array}$ & $\begin{array}{l}\text { F: } \\
\text { CATGGCAACAAGACCAAGT } \\
\text { GTC } \\
\text { R: } \\
\text { GTTGGGAACAAAGTAGGGA } \\
\text { CTG }\end{array}$ & 0.30 & 102 & \\
\hline DY475397 & $\begin{array}{l}\text { Superoxide } \\
\text { dismutase } \\
\text { copper } \\
\text { chaperone } \\
\text { precursor } \\
\text { (SDCCP) }\end{array}$ & $\begin{array}{l}\text { Detoxificatio } \\
\mathrm{n} \text { of reactive } \\
\text { superoxide } \\
\text { radical } \\
\text { anions } \\
\text { produced by } \\
\text { fungal } \\
\text { pathogen }\end{array}$ & $\begin{array}{l}\text { F: } \\
\text { TCTCACTCTCACCAATCCCT } \\
\text { AAA } \\
\text { R: } \\
\text { CCACCATAAACTCCGTCAGT } \\
\text { AAC }\end{array}$ & 0.30 & 205 & \\
\hline CV793599 & $\begin{array}{l}\text { Protein with } \\
\text { leucine- } \\
\text { zipper (LZP) }\end{array}$ & $\begin{array}{l}\text { bZIP } \\
\text { transcription } \\
\text { factors } \\
\text { regulating } \\
\text { salicylic acid } \\
\text { (SA) }\end{array}$ & $\begin{array}{l}\text { F: } \\
\text { AAGACATTGCATTGCAGCAG } \\
\text { R: } \\
\text { AAGACAAGGCTTTGCTCCAA }\end{array}$ & 0.30 & 176 & \\
\hline
\end{tabular}




\begin{tabular}{|c|c|c|c|c|c|c|}
\hline DY396298 & $\begin{array}{l}\text { Environment } \\
\text { al stress- } \\
\text { inducible } \\
\text { protein } \\
\text { (ESP) }\end{array}$ & $\begin{array}{l}\text { Environment } \\
\text { al stress } \\
\text { induced } \\
\text { protein }\end{array}$ & $\begin{array}{l}\text { F: } \\
\text { CGGGAATTCGATTAAGCAGT } \\
\text { R: } \\
\text { ACCGTTGTAACCACCTCCAC }\end{array}$ & 0.15 & 178 & \\
\hline $\begin{array}{l}\text { TF } \\
1070 . \mathrm{m} 000 \\
05\end{array}$ & $\begin{array}{l}\text { Myb, DNA- } \\
\text { binding, } \\
\text { Homeodoma } \\
\text { in like } \\
\text { (TF1063) }\end{array}$ & $\begin{array}{l}\text { Host defence } \\
\text { gene } \\
\text { (QTL }_{\text {AR1 }-} \\
\text { LG4) }\end{array}$ & $\begin{array}{l}\text { F: } \\
\text { GTTATGTGGGTGGAGTTGGA } \\
\text { A } \\
\text { R: } \\
\text { CAACCATAGCTGCAACCATC } \\
\text { T }\end{array}$ & 0.15 & 104 & $\begin{array}{l}\text { Madrid } \\
\text { et al. } \\
2010\end{array}$ \\
\hline TC101530 & $\begin{array}{l}\text { Pathogenesis } \\
\text {-related } \\
\text { transcription } \\
\text { al factor } \\
\text { (TF1082) }\end{array}$ & $\begin{array}{l}\text { Host defence } \\
\text { gene } \\
\text { (QTL }_{\text {AR2 - }} \\
\text { LG4) }\end{array}$ & $\begin{array}{l}\text { F: } \\
\text { AAGTCTTATCGTGGCGTTCG } \\
\text { R: } \\
\text { TCATAAGCTAGTGCTGCTGC } \\
\text { T }\end{array}$ & 0.15 & 131 & \\
\hline
\end{tabular}

\begin{tabular}{|c|c|c|c|c|c|c|}
\hline CR955005 & $\begin{array}{l}\text { Resistance } \\
\text { gene analog } \\
4 \text { - LG8 } \\
\text { (RGA 4) }\end{array}$ & $\begin{array}{l}\text { Chickpea } \\
\text { RGA } \\
\text { families } \\
\text { linked to } \\
\text { NBS-LRR } \\
\text { genes }\end{array}$ & $\begin{array}{l}\text { F: } \\
\text { GGCCATTGAATCAAGACGA } \\
\text { G } \\
\text { R: } \\
\text { CACATTTCACCACAATCTCC }\end{array}$ & 0.30 & 113 & $\begin{array}{l}\text { Palomin } \\
\text { o et al. } \\
2009\end{array}$ \\
\hline DY396288 & $\begin{array}{l}\text { Resistance } \\
\text { gene analog } \\
5-\text { LG2 } \\
\text { (RGA 5) }\end{array}$ & & $\begin{array}{l}\text { F: GAACGACGACCAAGATAC } \\
\text { R: } \\
\text { CCATTTACGACTTCCGCAC }\end{array}$ & 0.30 & 140 & \\
\hline AW774607 & $\begin{array}{l}\text { Resistance } \\
\text { gene analog } \\
7 \text { - LG3 } \\
\text { (RGA 7) }\end{array}$ & & $\begin{array}{l}\text { F: } \\
\text { GCGACCGTCTTGTATGACAC } \\
\text { R: } \\
\text { GGAGCTTCCTGTTGTATAGC } \\
\text { C }\end{array}$ & 0.30 & 211 & \\
\hline CX533869 & $\begin{array}{l}\text { Resistance } \\
\text { gene analog } \\
10 \text { - LG6 } \\
\text { (RGA 10) }\end{array}$ & & $\begin{array}{l}\text { F: TGCCGTATTGCTGATCTGA } \\
\text { R: } \\
\text { TAGATGCGTTGTGAAGATT }\end{array}$ & 0.30 & 124 & \\
\hline EU 339183 & $\begin{array}{l}\text { CarNAC } \\
\text { (CARNAC) }\end{array}$ & $\begin{array}{l}\text { Developmen } \\
\text { tal process } \\
\text { and plant } \\
\text { defense }\end{array}$ & $\begin{array}{l}\text { F: CTCTTTCCСTTTACCCG } \\
\text { R: TTGGCTTCTTTAGTGCTG }\end{array}$ & 0.30 & 243 & $\begin{array}{l}\text { Peng et } \\
\text { al. } 2010\end{array}$ \\
\hline DY396400 & $\begin{array}{l}\text { CaETRI } \\
\text { (Cicer } \\
\text { arietinum } \mathrm{L} \text {. } \\
\text { Ethylene } \\
\text { receptor-like } \\
\text { sequences) }\end{array}$ & $\begin{array}{l}\text { Ethylene } \\
\text { response - } \\
\text { induced } \\
\text { transcription } \\
\text { factor found } \\
\text { on QTL } L_{\mathrm{AR} 1} \\
\text { activated } \\
\text { against } A \text {. } \\
\text { rabiei } \\
\text { pathotype II }\end{array}$ & $\begin{array}{l}\text { F: } \\
\text { TAGGGTTTGGACCAAGCAAG } \\
\text { R: } \\
\text { CTTCTGAGACTGCTGCAACG }\end{array}$ & 0.30 & 151 & $\begin{array}{l}\text { Madrid } \\
\text { et al. } \\
2012\end{array}$ \\
\hline AJ515032 & $\begin{array}{l}\text { Polyubiquiti } \\
\text { n (PUBQ) }\end{array}$ & $\begin{array}{l}\text { House } \\
\text { keeping gene }\end{array}$ & $\begin{array}{l}\text { F: } \\
\text { AGGTGGAAAGTTCAGACAC }\end{array}$ & 0.30 & 80 & $\begin{array}{l}\text { Castro et } \\
\text { al. } 2012\end{array}$ \\
\hline
\end{tabular}




\section{AAT}

$\mathrm{R}:$ ACCTTTGCTGATCTGGTGGG

A

$\begin{array}{llllll}\text { AJ131050. } & \begin{array}{l}\text { Ribulose } \\ 1,5-\end{array} & \begin{array}{l}\text { House } \\ \text { keeping gene }\end{array} & \text { F: } & 0.30 & 192 \\ \text { biphosphate } & & & & \\ \begin{array}{l}\text { carboxylase } \\ \text { small }\end{array} & & \text { R: } & \\ \text { subunit } & & \text { TTGAACAGCCTCAGTGCAAC } & & \\ & & & \\ & \text { RIB }) & & & \end{array}$

661

662

Genesis090 - 09KAL09

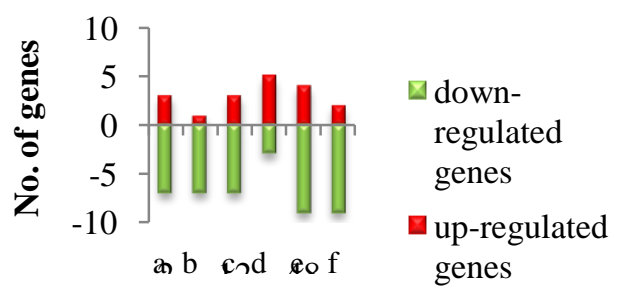

Hours Post Inoculation

663

Genesis090 - 09KAN19

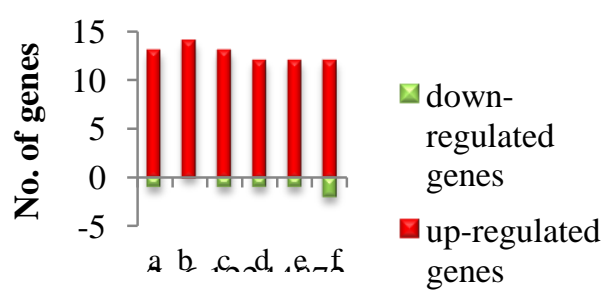

Hours Post Inoculation
Genesis090 - 09MEL04

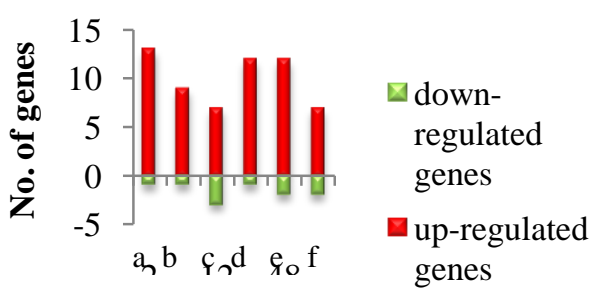

Hours Post Inoculation

Genesis090 - 09KIN11

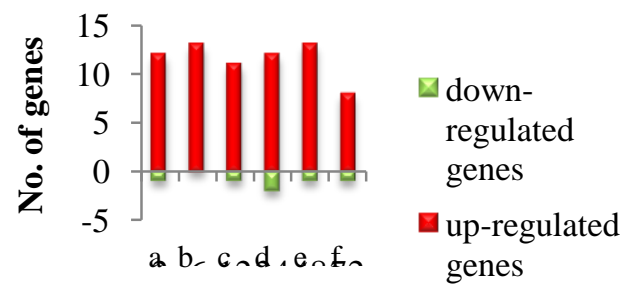

Hours Post Inoculation 
Kaniva - 09KAL09

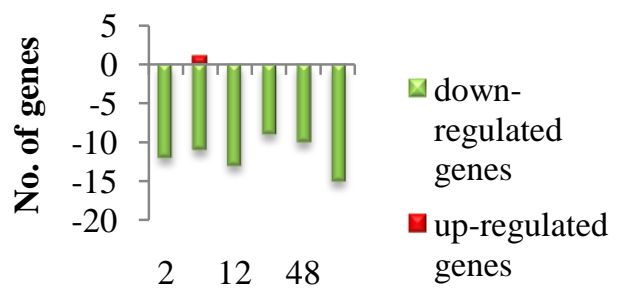

Hours Post Inoculation
Kaniva - 09KAN19

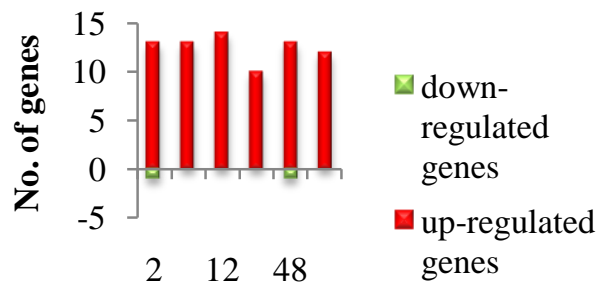

Hours Post Inoculation

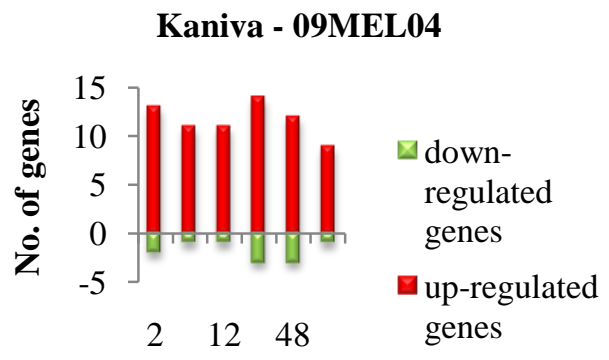

Hours Post Inoculation

Kaniva - 09KIN11

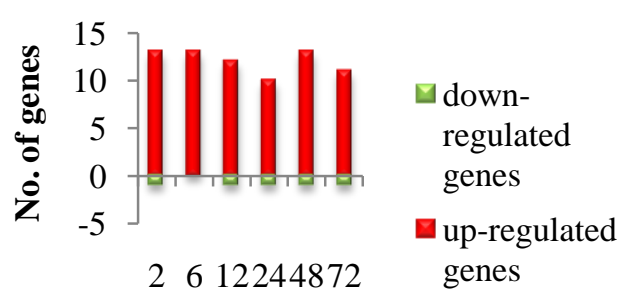

Hours Post Inoculation

667 Figure 1. Kinetic trends of differential gene expression for Genesis090 (resistant) and Kaniva 668 (susceptible) genotypes over the time course of infection: (a) 2 hpi; (b) 6 hpi; (c) 12 hpi; (d) 24 hpi; 669 (e) $48 \mathrm{hpi}$; (f) $72 \mathrm{hpi}$, with $4 \mathrm{~A}$. rabiei isolates, 09KAL09, 09MEL04, 09KAN19 and 09KIN11. The 670 vertical axis indicates the number of up-regulated (red) and down-regulated genes (green) at each time 671 point. 


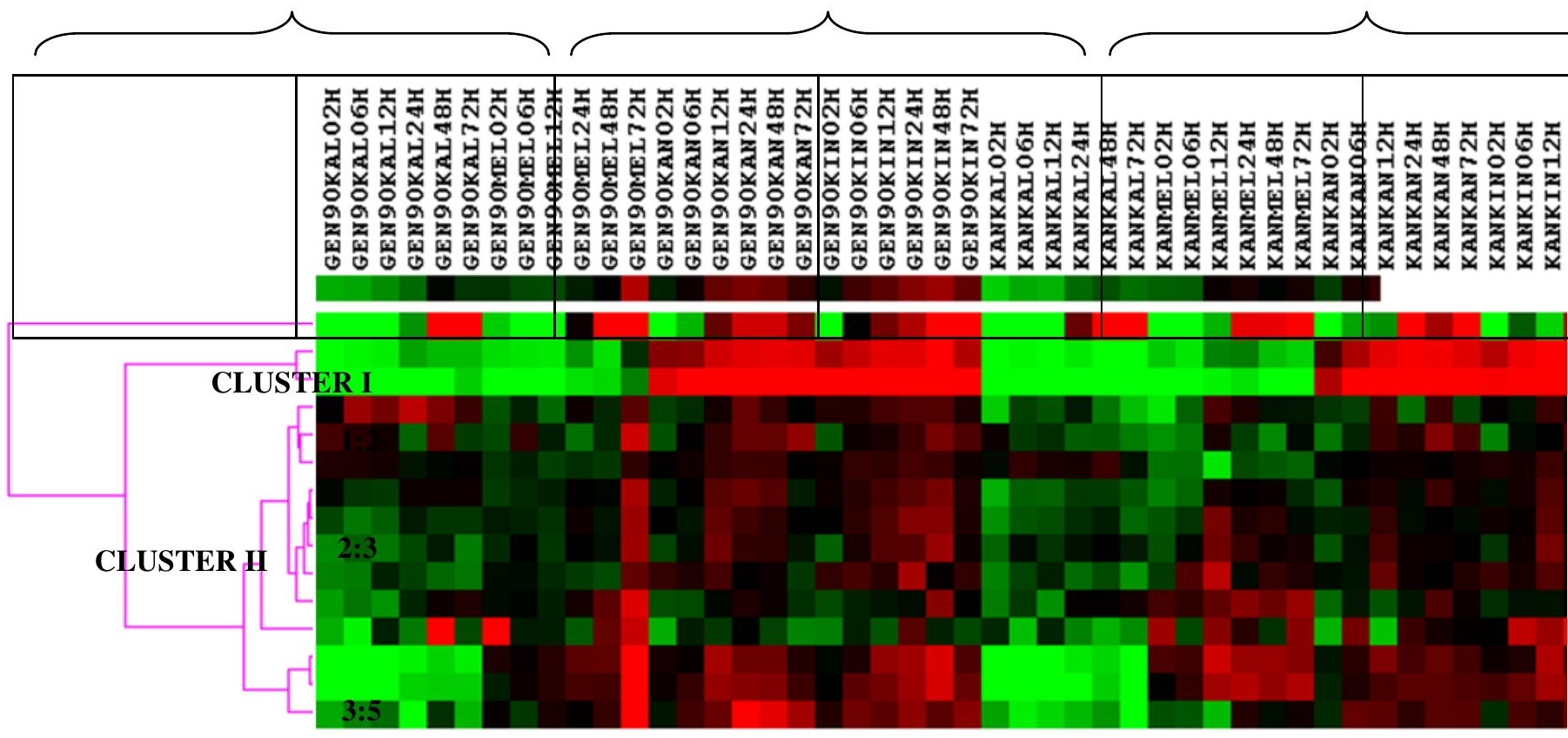

677 Figure 2. Heatmap of 15 genes expression profiles for Genesis090 (resistant) and Kaniva (susceptible) 678 over the time course after infection with 4 A. rabiei isolates, 09KAL09, 09MEL04, 09KAN19 and 679 09KIN11. Up-regulation is indicated in red, down-regulation is indicated in green, normalised 680 expression values close to the mean are in black. No detectable expression is in grey. The $\log _{2}$ values 681 of the expression profile for each treatment and genotype were normalised with two reference genes 682 and 


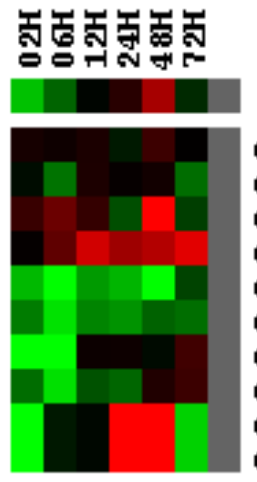

CARHAC 90102-50-1103

CARHAC ICC3996

CARKAC ALMAZ

CARWAC Genesis114

CARHAC 94-121*99\$4006

CARHAC FLIPPER

CARHAC PBA HatTrick

CARHAC HOWZAT

CARWAC Genesis090

CARWAC KALTVA

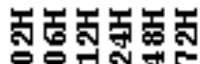



ERG 90102-50-1103

ERG HLMPZ

ERG ICC3996

ERG FLIPPER

ERG Genesis114

ERG 94-121*99Y4006

ERG PBA HatTrick

ERG HOWZAT

ERG Genesis090

ERG KALIVA

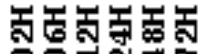
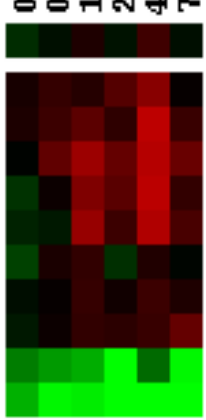

GST 90102-50-1103

GST ALMAZ

GST ICC3996

GST Genesis114

GST PBA PBA HatTrick

GST FLIPPER

GST 94-121 $99 \mathrm{Y} 4006$

GST HOWZAT

GST Genesis090

GST KAHTVA

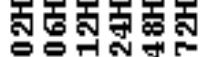

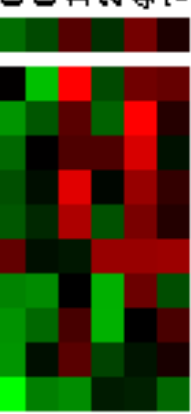

\section{PAMP FLIPPER}

PAMP ALMAR

PAMP ICC3996

PAMP Genesis114

PAMP PBA HatTrick

PAMP Genesis090

PAMP 90102-50-1103

PAMP 94-121*99U4006

PAMP HOWZAT

PAMP KALIVA

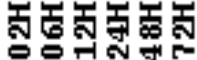

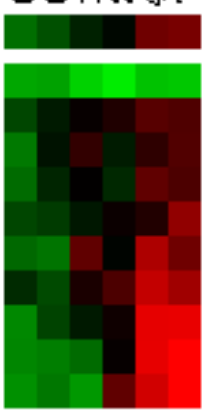

PR2B FLIPPER

PR2B ICC3996

PR2B 90102-50-1103



PR2B HOWZAT

PR2B Genesis114

PR2B PBA HatTrick

PR2B ALMAZ

PR2B Genesis090

PR2B KALTVA

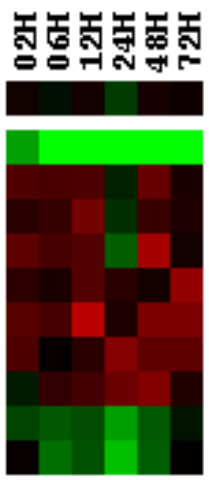

RGA4 ICC3996

RGA4 90102-50-1103

RGH4 FLIPPER

RGA4 ALMAZ

RGA4 94-121*99V4006

RGA4 PBA HatTrick

RGA4 Genesis 090

RGA4 KANTVA

RGA4 Genesis114

RGA4 HOWZAT


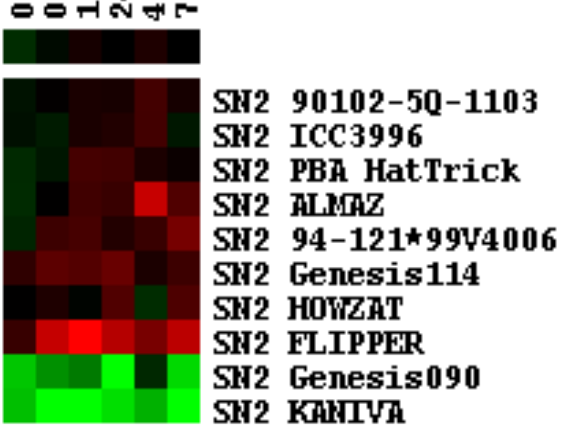

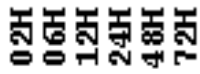
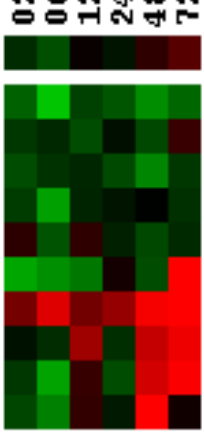

TF 1082 ICc3996

TF 1082 90102-50-1103

TF 1082 FLIPPER

TF 1082 PBA HatTrick

TF 1082 KAHTVA

TF 1082 Genesis114

TF1082 94-121^99V4006

TF 1082 ALMAZ

TF 1082 HOWZAT

TF1082 Genesis090

685 Figure 3. Heatmap of eight genes expression profiles for 10 chickpea genotypes (Table 1) over the 686 time course after infection with the most pathogenic A. rabiei isolate, 09KAL09. Up-regulation is 687 indicated in red, down-regulation is indicated in green, normalised expression values close to the 
mean are in black, no detectable expression is in grey. The $\log _{2}$ values of the expression profile for 689 each treatment and genotype were normalised with two reference genes and non-inoculates samples. 


\section{University Library}

\section{- M M I N E R VA A gateway to Melbourne's research publications}

Minerva Access is the Institutional Repository of The University of Melbourne

Author/s:

Leo, AE;Linde, CC;Ford, R

Title:

Defence gene expression profiling to Ascochyta rabiei aggressiveness in chickpea

Date:

2016-07-01

Citation:

Leo, A. E., Linde, C. C. \& Ford, R. (2016). Defence gene expression profiling to Ascochyta rabiei aggressiveness in chickpea. THEORETICAL AND APPLIED GENETICS, 129 (7), pp.1333-1345. https://doi.org/10.1007/s00122-016-2706-2.

Persistent Link:

http://hdl.handle.net/11343/283166 